\title{
Inter-Faith Harmony Forum and the Ethnographic Stories: Behind the Harmonious Life of Malang People
}

\author{
Hipolitus Kristoforus Kewuel ${ }^{1}$, Franciscus Apriwan ${ }^{2}$, Aji Prasetya Wahyu Utama ${ }^{3}$ \\ \{hipopegan@ub.ac.id ${ }^{1}$,f.apriwan@ub.ac.id ${ }^{2}$, aji.utama@uia.no ${ }^{3}$ \} \\ Universitas Brawijaya, Indonesia ${ }^{1,2,3}$ \\ University of Agder, Norway ${ }^{3}$
}

\begin{abstract}
The article reveals the important role of Inter-Faith Harmony Forum (IFHF) in ensuring the harmony of life among religious communities. IFHF, we argue, has constructive effects to encourage interaction and communication among distinct religious adherent. The forum is reducing social barriers that was previously segregating them in groups. Therefore, IFHF is not merely active in the scope of religion, but also the social, cultural, and political spheres. The role of IFHF in those spheres gives a distinctive touch to stimulate a sense of solidarity and the importance of the harmonious of religious life, especially in specific Malang community. In the social sphere, the forum facilitates comfortable meetings for communities. While, in the cultural sphere, unique and targeted approaches allow people to be comfortable during communication. Furthermore, in the political area, it bridges people's aspirations that precede to government policy. The research employs specifically ethnography methods, collaborating qualitative interpretation of selective subjects and group discussions.
\end{abstract}

Keywords: Inter-faith Harmony Forum, Facilitator, Social Cultural Space, Political Space, Harmonious Life

\section{Introduction}

Coexistence is a concrete reality that people have always struggled with at any level of society [1]. In traditional society, most of the life struggles focus on the collective efforts to survive. It may include surviving enemy attacks, starvation, plague, and even existential anxiety in dealing with the difficult situations, for instance, it could be about God and how to deal with the mysteries of natures or even death [2]. Therefore, living in harmony becomes a vital requirement in society. Togetherness becomes their strength in dealing with those hardships. Kewuel concluded that the presence of religions is an example of community togetherness in distress, where anyone cannot claim as the best or the most perfect. Every one of them is in the middle of endless searching.

In modern society, advances in science and technology have made it possible for people to live independently almost without relying on others [3]. People can live together in dense solitude and fight for themselves. They are not honed to think about others. This situation is prone to conflicts. The slightest conflict of interests could become a significant problem. It is a profane problem that can be solved where logic is present in the meeting space. It becomes more complicated when the conflicts occur in the realm of religion, where the meeting space involves faith, not logic [4]. Religious differences can easily ignite conflict, and the state has recognized this since its inception. In recent years, various national media have reported on various cases 
of religious intolerance. In 2018, Media Indonesia reported sea offerings rituals in the south coast of Yogyakarta was dissolve by unknown group [5]. A cross-shaped gravestone was found cut off at a village cemetery in 2019 [6]. In 2020, there was an incident in West Java that Christian worshiping was dismissed though it was held at home [7]. The above evidences show a recent increase tension among religious communities. Moreover, it demands solutions urgently. The establishment of Inter-Faith Harmony Forum across Provinces and Regencies/Cities is a means to oversee this matter. Malang City is nationally known as a relatively safe area from religious conflicts.

The efforts to build harmony among religious communities in Indonesia are based on Article 29 of the 1945 Constitution; (1) The state in virtue of the Believe in the One and Only God. (2) The state guarantees the freedom of each resident to embrace their religion and to worship according to their faith and belief. This law guarantees the spiritual life of its citizens. The law has become a foundation for establishing the Ministry of Religion in Indonesia to participate in regulating the religious life of all citizens [8].

It is unique because in many countries matters of religious life are not regulated by the state in executing its legislature [9]. Muntoha emphasized that in Indonesia, religion and state are recognized as two things that control the life of the people both physically and spiritually. In terms of faith, the state regulates the spiritual life of the people who have physical activities that need to be regulated. This situation differs from one country to another due to the historical background of each country. That is why the instruments of coexistence regulation cannot be equated from one country to another. The founding fathers of Indonesia had determined such regulation through careful and deep considerations. Such regulation came from a specific philosophy of Indonesia. The philosophy referred to here is the divine entities that exist in Indonesian society throughout its history [10].

However, it frequently ignites a discussion; why the Indonesian Government, in running the state, partakes in regulating the religious life of its citizens, although religion is a private issue [11]. Dahlan argued that the space for discussion, in general, revolves around the form of the state and its responsibilities. This logic is valid and can be accounted for because clashes in the implementation happen, where the boundaries between the role of the state and the private space of society are thin and blurred, and this is difficult to avoid in practice [12].

However, if we take a closer look, the state's interference as stipulated in Article 29 of the 1945 Constitution is not in the context of interfering the private space, but rather guarantees the establishment of the private space. The citizens are guaranteed the freedom to choose and embrace their religion. The citizens are guaranteed the freedom to perform religious rituals and worship according to their beliefs. With this guarantee, no citizen can be forced to embrace a specific religion [13]. Thus, the state does not interfere in the private issue of religious communities, to be precise, it guarantees every citizen's comfort in religious life so they will not be disturbed in conducting their religious activities [14]. However, Hafiz warned that in the process of guaranteeing religious freedom, the state needs to maintain a balance between ideal norms, practices, and local wisdom of each region. The state must also provide sacred living space for its citizens to ensure the continuity of divine experience, which is thick in the history of the Indonesian state's journey. Religious human rights are not a gift from the state or a gift from certain groups, but it is inherent in our humanity. Hence, there is nothing that needs to be questioned regarding the human rights of religion [15].

On the other hand, it is understandable that private space in coexistence needs to be arranged for the coexistence. It is not to regulate and control the essence of private space, but to organize the traffic in living comfortably and beautifully amid life differences [16]. Life is beautiful because there are differences. The combination of two different things is even more 
likely --and in fact, it is-- to give birth to new ideas. IFHF was born as an instrument to help Regional Leaders in ensuring harmony between religious communities in their respective regions. On the one hand, it is realized explicitly that religious differences have significant potential for conflict in social life. On the other hand, this shows an existential awareness that conflict must be processed without prior cases as the trigger [17]. Sharma explained that in the world of education, preparation for multicultural learning is necessary since students' diversity in various aspects cannot be predicted and is considered trivial. Diversity encourages us to be anticipatory or preventive. Readiness attitude is helpful when religious conflicts arise in society. With principles of coexistence, different religious conflicts are easier to intervene to find a way to resolve them [18].

Not only IFHF responsible for its sustainability as an organization, it is also responsible for the process and mechanism for the establishment of house of worship, which is one of the most vulnerable matters in the relationship among religious communities. House of worship is one of the most concrete representations of religious differences. Therefore, it can be understood that the construction of house of worship becomes a critical point for conflicts recurring from one place to another [19]. If only there are areas where the process of establishing houses of worship is facile, that would be an interesting sign of the diversity of life in the community. The area would be the pilot area and widely referred to for religious harmony learning. In overcoming the problems arising from the establishment of houses of worship, it is necessary to adopt a multi-perspective approach from sociological, anthropological, legal, political, and other perspectives. Conflicts due to the establishment of houses of worship cannot be resolved with only one perspective. Due to the complexity of the multi-perspective problem, it is common that in the process of resolving conflicts over the establishment of house of worship, there are three occurring possibilities. First, the establishment of house of worship is problematic but resolved, second, the establishment of house of worship is problematic and unresolved, and the establishment of house of worship is not problematic [20].

This research is a follow-up study of the mapping study on the organizational condition and job description of IFHF Malang Raya [21] which specifically investigated the concrete efforts of Malang City in managing the diversity of religious life. Specifically, this research aimed to reveal the dialogue patterns developed by IFHF Malang City, not only the formal strategies, but also the practice in the field. It covered how they meet in person and have a dialogue with the community; how they help the community resolving conflicts of relations between religions; how they struggle to train frontlines to have a dialogue between religious communities; and how they perform the role as a mediator of development between the community and the Government. Such information was expected as the findings of this research so that the presentation of ethnographic writing becomes the core in writing the IFHF Malang City activity report in building dialogue between its citizens.

\section{Method}

This research employed ethnographic qualitative methods conducted in April up to November 2019. The ethnography combined several data collection techniques, namely observations, in-depth interview, and focus group discussions (FGD). Data collection specific targeted IFHF staff as well as specific community as recipients. Through in-depth interviews, this research explored various information about IFHF's roles in building harmonious life within the community. Through the observation method, information that is difficult to disclose orally can be processed to sharpen the research conclusions. The results of interviews and observations 
were then processed in a Focus Group Discussion (FGD) to finalize and bring various perspectives together to support a more qualified research conclusion. All of these qualitative field methods were used because humans, as the subject of the information, are unique creatures who do not always wholly disclose what they understand and experience. In the step of analysis, this research relied on the acuity of qualitative data analysis through clarity of understanding (verstehen) and the depth of interpretation. It does not rule out that in extracting the data, some data are not in line with expectations and even deviates from the research theme. Such findings were not alienated but were analyzed to find the antagonistic contribution to coexistence. It was important to refine the quality of harmony of coexistence further.

\section{Result and Discussion}

The results of this research indicate that IFHF Malang City has been carrying out activities to participate in building harmony in the community's life. First, the activities that are directly attached to its main tasks and functions, for instance, overseeing the process of house of worship establishment. Second, performing mediation to hear and accept the aspirations from the community. Third, performing mediation to channel the community's aspirations to the Government. Fourth, socializing information about IFHF regulations and policies. Fifth, performing mediating dialogue among religious leaders, as well as between the community leaders and religious leaders.

Concerning the task of overseeing the process of establishing house of worship, it is said that many parties oversimplify the problem. Many conditions must be fulfilled to establish a house of worship [22]. The essential requirement, according to the Head of IFHF Malang City, H. A. Taufiq Kusuma, the construction of a house of worship must be approved by the residents around the area. He said, this requirement has been regulated in great detail, that there must be data of 90 user citizens and data of 60 supporting citizens.

The problem arose from the requirement of 90 user citizens, according to Taufiq, it is usually mediated by giving an understanding to residents of other beliefs about the position of minority religion which makes it impossible for its followers to gather in one area. "Why is this crucial? Because the Joint Ministerial Decree does not provide a detailed explanation of this point. Sometimes we succeed, but sometimes we fail. The failure is because the majority of residents adhere to the rules and regulations, and it usually diminishes residents' support for the establishment of house of worship. For residents who fail to build house of worship, we assist in understanding and to grasp the concrete situation that occurred. That way, we can learn that not every plan goes according to the plan", he said. In many cases, it can potentially ignite conflicts. However, with a proper approach and management, this potential conflict can be reduced [23]. Farida emphasized that Indonesians can manage religious disputes. The emphasis refers to the revitalization of socio-cultural institutions as a cultural element that lives, grows, and develops in society.

Problems often arise from the use of houses or shophouses as places of worship which certainly do not pass the permit procedure for the establishment of a house of worship [24]. In such cases, the issue could be raised from many sides. An employee of IFHF office in Malang City, Dani, said that there was such an issue that had happened in Malang. "The issue arose from a parking matter. It escalated to the permit to use the shop as a house of worship. At that time, the forum administrators conducted mediation by asking the shophouse users to seek a permit from the shophouse owner, which was then reported to the village/sub-district 
authorities, IFHF, and the Head of the Office of the Ministry of Religious Affairs in Malang City. This is a part of the organization's efforts to defuse the situation and build a basis for legality even though it has violated the actual procedure", said Dani.

The same thing happened to other minority religious communities. The Catholics, Confucians, Hindus, and Buddhists also experience similar problems when they want to build houses of worship. IFHF mediated it by suggesting a thought that most minority religious communities are migrants who will not settle permanently in Malang. Therefore, it was understood that their need for a house of worship might only be temporary in a resident's house.

On the other hand, Catholic representative of IFHF, Nugroho, said there is often a bias to the discussion about the establishment of houses of worship. Government regulations only consider the ratio of the number of people to the needs of a house of worship, including the location of the community's domicile. This is often confused by issues of the spread of religion, which get a lot of response from the community. "So, sometimes, the problem of the establishment of houses of worship is a problem in parts that are not substantial. It is not a matter of location and the ratio of the number of people, but rather the issue of fear of the spread of the religious minority", said Nugroho. It is understood because one of the main activities of religions is the dissemination of religious teachings. It is natural for such concerns to arise in the context of the establishment of houses of worship and this must happen to every religious person.

Regarding IFHF program as a mediator between the community and the Government, the chairman, H. A. Taufiq Kusuma explained that in this case, his organization is responsible for two roles at the same time, the role to listen to the aspirations of the community and the role to communicate these aspirations to the Government. Taufiq also added that the role mediator is an essential part of IFHF's duties as a forum formed by the community with the aim of building, maintaining, and empowering religious communities for the sake of harmony and welfare.

In IFHF's work, aspirations are interpreted as an expression of people's hopes for a better future of coexistence. It is recognized that such expectations will be realized if carried out in the context of governance. Thus, communicating people's aspirations to the Government is one of the key functions of the organization. Taufiq added, the purpose of accepting aspirations also occurs in preparing the program and activities implementation. He pointed out that assistance in the establishment of houses of worship also started from the aspirations of the community to build these houses of worship. Therefore, IFHF in doing its duties, always starts from aspirations and needs that are experienced by the community.

Mediation is always needed because there are pros and cons in every aspiration. This is where conflicts sometimes occur [25]. IFHF is positioned as the mediator in each of these situations. One of the examples is the establishment of a house of worship (church) for Catholics in Landungsari, Malang. The context of house of worship establishment originated from the permit to renovate the church because of its insufficient capacity. It drew protests from the surrounding community. In the end, the renovation was cancelled and rumor to ban the church emerged even though the place had been used for years. The role of mediation in religious conflicts must always be open to all kinds of possible outcomes, it can succeed, but it can also fail [26].

In this case, IFHF conducted several mediation steps. It includes an approach to the community, from the Government through the Neighborhood Unit/Community Unit, even mediation between religious leaders, but they got no results. The residents adhere to the principle that the number of users does not meet the requirement. Unconsciously, this matter leaves a prolonged dispute not only between individual members of the community but also 
disputes in religious communities that seem subtle but are full of disputes just like what happened in Nigeria [27].

According to Catholic religious figure, Father Hugo, the approach of this situation could not be done abruptly. He said there must be a process that precedes it, such as building a good relationship pattern, showing good intentions and wills in everyday life as a citizen. "The Catholics must not be exclusive in their daily interactions; they must mingle with the surrounding community. Only through this kind of cultural effort can cases like this be suppressed. The Catholics are challenged to build good social relations with the community. The Catholics need to appear as good figures in the community, and that is the most basic asset. If this is done and occurred naturally in everyday life, likely, it will not be rejected as it is", he said.

In connection with the task of socializing IFHF laws and policies, this forum collaborates with community organizations. The socialization that is often carried out is the laws and regulations relating to the establishment of houses of worship. Vice-Chairman 1, as well as the representative of Christians, Stefanus, revealed that this was their main concern because, in society, it is a sensitive matter. Socialization is usually carried out in religious communities, community organizations, and more often the socialization is carried out when there are conflicts over the establishment of houses of worship.

Starting from this matter, Stefanus realized the importance of a study about solving these cases. The context of the study in question is an intensive discussion between the community or the parties involved with the government and religious leaders. One example is the case experienced by the Hindu community in Buring, Malang. The materials for the offerings that they put down as ritual media were taken by the non-Hindu community around the shrine (Pure). The Hindu community was annoyed and reported it to IFHF. The problem was solved through intensive socialization to the community through the Neighborhood Unit/Community Unit. As a result, people gradually realize and do not disturb (Hindu community) anymore, even there is a form of excellent mutual understanding. The community maintains and protects the Hindu community's worship, and also actively participates in providing and managing the parking lots.

Socialization is also carried out on campus to educate young generation to have insight into the life of religious harmony [28]. Before the socialization, many students did not have extensive knowledge about religious coexistence. Those who have only thought and been diligent with their religion and their affairs have become open and aware of the importance of having broad insights into other religions. A migrant Hindu student, Javas, admitted that as a religious minority, they got complete information about the map of the Hindu community in Malang through IFHF socialization. "I came to know the Hindu community in Malang, so even though I am a migrant student, I have no trouble carrying out the worship", he explained.

In addition to informative matters, the importance of this socialization is now increasingly being perceived, especially to compensate for various irresponsible news and information spreading through social media. Currently, the coverage on social media appears almost unethical. Anyone can be an informant. The circulating news no longer passes the news content selection as to how it is in the conventional journalism principles. Everything is simply thrown onto social media without censorship. That is why, nowadays, the importance of socialization through social media increasingly becomes a challenge for the forum. Sooner or later, IFHF's socialization channels through social media need to be seriously considered. In several cases, it is clear that the trigger for the problem of religious harmony comes from irresponsible reporting on social media [29].

Furthermore, the role of IFHF is to become a mediator between the religious leaders and community leaders. This role is intended to bridge the resolution of conflicts occur in society 
with the assumption that conflicting parties are easier to be approached and provided understanding by the community leader who lives with them daily [30]. With this, the members realized that the role of the formal institution and coming from outside of the community often do not provide significant benefits that might even turn the conflicts worse. IFHF is a multiculturalism institution in Indonesia, but with this pattern, its members do not act arbitrarily in carrying out their duties. They realize that as mediators, their strength is to activate the role of the community in solving various causes related to religious conflicts at any level. Thus, IFHF maintains its position as a neutral professional institution.

IFHF Malang City does not only present for conflict, but they are also actively having dialogues with community leaders to encourage tolerance in everyday life as a measure to prevent conflicts. It is a routine for the members to go around from one religious' community to another to build a common perception in maintaining religious harmony. That is why the main activity of IFHF's members is to be there with the community. It is understandable why IFHF's office facilities only appear as they are, almost without employees, and joint activities only take the form of a coordination meeting once a week. It shows that the role of religion is not only to maintain a relationship with God but also to care for relationships with others by maintaining human values. Kung even drew it in the context of global ethics which concerns the behavior of religious people in all aspects of life [31])

The routine in the community includes; dialogue with the Government, community leaders, IFHF Malang City members, and the fellow members from other areas. Therefore, there is a comparative study program to the similar forum in other regencies or cities, and vice versa, there is a visit by IFHF of other cities to IFHF Malang City. In these forums that IFHF Malang City simultaneously performs the function to accommodate and communicate the aspirations of the community. Interestingly, the forum's work is under local government monitor that is involved as the advisory board, including the Deputy Mayor as Chairperson, Head of the local Ministry of Religion Office as Deputy Chairperson, Head of the National Unity and Political Body as Secretary, and heads of related agencies as members. Thus, IFHF work becomes a concern and is always under the supervision of all elements of Government. Every government policy related to religion is always communicated to the forum for the socialization to the public with the hope that harmony among religious communities can become a strategic asset and support for regional development [32].

\section{Conclusions}

Malang City is nationally known safe from religious conflicts. Even though there was, it did not emerge as a national issue. The answer to this phenomenon is slightly revealed by tracing through this study regarding the role of IFHF Malang City in building community harmony. It turned out that the forum members in Malang City have not only carried out their duties formally. They struggle with real harmony issues in society. Sometimes they fail, sometimes they manage to thrive.

There is a work pattern that they build systematically. Five main projects have become their focus. The projects include regulating and facilitating permits for the establishment of house of worship, receiving and channeling community aspirations, socializing the regulations and policies, and conducting dialogue with religious and community leaders. This research is an initial mapping. Therefore, it is still a description of what IFHF Malang City does. Critical discussion on the various activities is an essential recommendation for further research on which orientation is to give more weight to the IFHF Malang City activities. Thus, the research 
becomes an integral part of the efforts of IFHF Malang City to increasingly allow the residents living in a harmonious and peaceful atmosphere.

\section{References}

[1] D. H. Jennings, "Problems of living together," Nature, vol. 326, no. 6109, pp. 225-225, Mar. 1987.

[2] H. K. Kewuel, "Memandang Tuhan Dari Balik Pengalaman Kejahatan, Penderitaan, Dan Kematian," J. Pendidik. Agama Katolik, vol. 4, no. 2, pp. 264 - 278, 2010.

[3] P. Parvin, "Personal Autonomy in Society," Contemp. Polit. Theory, vol. 6, no. 4, pp. 492-496, Nov. 2007.

[4] H. K. Kewuel, “Allah Dalam Dunia Postmodern,” Universitas Gadjah Mada Yogyakarta, 2004.

[5] Media Indonesia, "9 Orang Ditangkap Terkait Sedekah Laut," Media Indonesia, 2018. [Online]. Available: https://mediaindonesia.com/nusantara/190599/9-orang-ditangkap-terkait-sedekahlaut.

[6] R. A. Sadikin, "Salib Dipotong hingga Tolak Sedekah Laut, 4 Kasus Intoleransi di Yogyakarta," Suara.com, 2019. [Online]. Available: https://www.suara.com/news/2019/04/03/163344/salibdipotong-hingga-tolak-sedekah-laut-4-kasus-intoleransi-di-yogyakarta?page=3.

[7] C. Lova, "Ibadah di Rumah Saat PSBB Dibubarkan Tetangga, Polisi Bilang Itu karena Salah Paham," Kompas.com, $2020 . \quad$ [Online]. Available: https://megapolitan.kompas.com/read/2020/04/20/10213331/ibadah-di-rumah-saat-psbbdibubarkan-tetangga-polisi-bilang-itu-karena.

[8] Tirto, "Sejarah Lahirnya Kementrian Agama RI yang Tak Sempat Disetujui," 2020.

[9] M. Muntoha, "Otoritas negara dalam pengaturan kehidupan beragama di Indonesia: Urgensi ataukah Intervensi?," in Millah, 2012, p. 540.

[10] M. Anas, Buku Ajar Pendidikan Pancasila. Pusat Mata Kuliah Pengembangan Kepribadian, Universitas Brawijaya, Malang, 2019.

[11] M. Dahlan, "Hubungan Agama dan Negara di Indonesia," Anal. J. Stud. Keislam., pp. 1-28, 2014.

[12] H. Setiawan, "Pro-Kontra Pembubaran (Sebagian) Kementerian Agama," Kompasiana, 2015.

[13] I. M. Rahmat, "Jaminan Kebebasan Beragama dan Berkeyakinan di Indonesia," J. HAM, vol. 11, pp. 1-34, 2014.

[14] M. Hafiz, "Jaminan Kebebasan Beragama: Norma Ideal, Praktik dan Lokalitas," J. HAM, vol. 11, pp. 63-94, 2014.

[15] D. Effendi, "Jaminan Konstitusional Bagi Kebebasan Beragama di Indonesia," in Passing Over: Melintasi Batas Agama, PT. Gramedia Pustaka Utama in collaboration with Yayasan Wakaf Paramadina: Jakarta, 1998, pp. 111-122.

[16] B. R. Bonnis, "Canada: Multiculturalism, Religion, and Accommodation," Electronic Thesis and Dissertation Repository, 2015. .

[17] S. Sharma, "Multicultural Education: Teachers' Perceptions And Preparation," J. Coll. Teach. Learn., 2015.

[18] H. K. Kewuel, "Sistem Pendidikan Nasional dan Kurikulum dalam Perspektif Filsafat Antropologi," Erud. (Journal Educ. Innov., vol. 2, no. 2, 2014.

[19] A. M. Aji, "Identifikasi Potensi Konflik Pra dan Pasca Pendirian Rumah Ibadah di Indonesia," Mizan J. Ilmu Syariah, vol. 2, no. 1, 2014.

[20] S. Man, "Problems of the establishment of worship houses in Pati, Central Java," Analisa, vol. 22, no. 2, p. 187, Dec. 2015.

[21] H. K. Kewuel, "A Long Way to Go for Diversity: The Fight Portrayed by Inter-faith Harmony Forum in Malang Raya," J. Moral Kemasyarakatan, vol. 5, no. 1, pp. 1-9, 2020.

[22] H. K. Kewuel, "Pemikiran Soren Kierkegaard tentang Hakikat Agama: Kontribusinya Bagi Dialog dan Kerukunan Hidup Antar Umat Beragama di Indonesia,” Universitas Gadjah Mada Yogyakarta, 2013.

[23] A. Farida, "Manajemen Konflik Keagamaan Melalui Jaringan Kerja Antar Umat Beragama Di Bandung Jawa Barat,” J. “Al-Qalam,” vol. 21, no. 1, pp. 141-152, 2015. 
[24] F. Nuraini, "Studi Kasus Penggunaan Rumah Tinggal Sebagai Tempat Ibadah Bagi Umat Kristen Batak Protestan Di Pondok Benowo Indah, Babat Jerawat, Pakal, Surabaya (Tinjauan Terhadap Konflik Antarumat Beragama Dalam Perspektif Ralf Dahrendorf," Universitas Islam Negeri Sunan Ampel, 2018.

[25] Karmawan, "Diskursus Mediasi dan Upaya Penyelesaiannya," KORDINAT, vol. XVI, no. 1, pp. 107-126, 2017.

[26] J. Haynes, "Conflict, Conflict Resolution and Peace-Building: The Role of Religion in Mozambique, Nigeria and Cambodia," Commonw. Comp. Polit., vol. 47, no. 1, pp. 52-75, Feb. 2009.

[27] M. A. Ojo and F. T. Lateju, "CHRISTIAN-MUSLIM CONFLICTS AND INTERFAITH BRIDGE-BUILDING EFFORTS IN NIGERIA,” Rev. Faith Int. Aff., vol. 8, no. 1, pp. 31-38, Jan. 2010.

[28] P. E. Michaelides, "Interfaith dialogue in global perspective and the necessity of youth involvement," Asia Eur. J. Stud. Common Policy Challenges, no. 449, 2009.

[29] H. K. Kewuel, "Journalism Ethics And Role of Interfaith Harmony Forum in Social Media," WASKITA, vol. 3, no. 2, pp. 17-26, 2019.

[30] K. Toweren, "Peran Tokoh Agama Dalam Peningkatan Pemahaman Agama Masyarakat Kampung Toweren Aceh Tengah,” DAYAH J. Islam. Educ., vol. 1, no. 2, pp. 258-272, 2018.

[31] H. Kung, A Global Ethic for Global Politics and Economics. Oxford University Press: New York, America.

[32] R. Tina, "Promoting a culture of peace and non-violence in Africa through education for peace and conflict prevention," Unesdoc Digital Library, 2013. . 